\title{
Exploring language errors in culturally diverse classrooms
}

\author{
Yevgeniya B. Novikova - Irina P. Gotovtseva -Alexandra A. Lukina - Daria \\ V. Sukhorukova
}

\section{DOI: 10.18355/XL.2017.10.04.30}

\begin{abstract}
This paper considers the investigation of language errors in students' speech and the mechanisms to prevent them. The types of errors (phonetic, grammar, lexical and syntactical errors) made by student from culturally diverse backgrounds are analysed. The purpose of the paper is to discuss approaches, which can help meet students' needs and highlight the problems, which students at non-linguistic higher schools might face. The teacher has also to play the role of a facilitator of better studying as ethnic, cultural and religious diversity in classroom makes the teaching process even more challenging. It is noted that the special methodological techniques will be really helpful to prevent students from negative feelings of inadequacy about their pronunciation, grammatical errors, limited vocabulary, and lack of information about cultural patterns within their new community.
\end{abstract}

Key words: Standard English, ethnic diversity, linguistic diversity, ethnically homogeneous group, language variety, linguistics interference

\section{Introduction}

In the XXI century the English language has gained the title of the world's lingua franca due to strengthening of business, political and scientific relations. Historically, communication among people with different mother tongues has always been stimulated by the continuing growth of the world economy. But when using the word 'English' one may assume that it refers to a standard of usage which everyone agrees on. However, over the years English has become more and more varied, and the notion of Standard English is now a notion that does not have as clear borders as it used to.

Understanding and accepting blurred borders within English is quite important, as it plays a key role even in regions where the United Kingdom never had much influence. In Western Europe most schools view it as the main foreign language, moreover in Asian countries such as South Korea, China and Japan students express the desire to know English. Before World War II there was little discussion of the notion of Standard English. It was mainly due to the fact that the UK had complete control over the development of the language itself and the way it was taught. Most textbooks and educational materials were written in British English and published in the UK. The whole situation showed the dominance of the United Kingdom in the sphere of English teaching.

Everything changed after 1945 when the USA started to acquire more and more power - in economy, culture and other spheres. Thus, students and teachers had to take into account the increasing role and popularity of American English. Since then the influence of the US led to an increasing impact of any other culture on the English language - Americans 'opened' the language to outer forces. Today the ideas concerning Standard English vary dramatically.

What is meant by Standard English? How can we define it? According to Oxford Dictionaries Standard English is the type of English that is suitable for use in every type of written or spoken situations. One of the main advantages of using Standard English is that it makes it possible to make communication effective and 
clear to a wide audience. But is it Standard British English, American or anything else?

In fact, this issue is still being under discussion. There exists no governing body, which would offer a clear agreement on what ESL students are to learn. However, it is necessary to understand that recognizing English as a multicultural language will help ESL learners develop a broader view on a rapidly changing world, extending their interests connected with learning about cultures and languages.

Another important idea is that teachers should be the first to accept this situation and to acknowledge the existence of many varieties of the English language and the fact that Standard English is difficult to define. They need to be ready to explain it to their students, so that every new generation remains open to all the possible influences on English that can be caused by each and every culture in the world.

The purpose of this article is to discuss approaches, which can help satisfy students' needs and highlight the problems, which students at non-linguistic higher schools might face, as ethnic, cultural and religious diversity in classroom makes the process of teaching even more challenging, that is why the teacher has also to play the role of a facilitator of better studying. It is essential to take into consideration the learning background of the students and the possible influence that their culture can have on the process of studying and on the way that they have acquired the English language. All these peculiarities make teacher's work quite complicated. All these aspects are incorporated into the notion "ethnic diversity". The language is influenced by teachers, lecturers, learners and those who prepare the educational materials. Thus, ethnic diversity should be viewed as one of the primary factors in the development of language. Today its influence is undeniable, but it can have both positive and negative impacts on the language learning process, and it is the mail goal of FL teaching.

In ethnically diverse classrooms students are likely to help each other to overcome certain difficulties, as they have different perception of the language and probably different capabilities and potential (Windzio, 2013). Therefore, it is essential for FL teachers to adapt learning materials and educational programs to such a group.

If one works with a diverse group, the curriculum itself will represent a challenge for students initially have low level of language competence .Such students have to adapt to a new educational context as quickly as possible, as the teacher will mostly try to increase the level of difficulty based on the average level of the group.

This is directly connected with another positive impact of ethnic diversity. Those students who seem to better understand and grasp the new material tend to master English better. Their cooperation with mediocre students can be mutually beneficial in terms language acquisition. All these factors show the positive side of teaching an ethnically diverse group of students, which can in the long term contribute to the higher rating of the educational institution.

However, diversity in language education can be viewed negatively if we look at a diverse group of students from the teacher's point of view. It is more difficult for a teacher to choose the methods when a group is diverse. When working with a more homogeneous group a teacher has a better chance of choosing the right methods of teaching, which increases the effectiveness of the whole process. It is obvious that the absence of ethnic diversity means that no time should be spent on bridging the gap between cultures. But when students leave the educational institution, they will have to communicate not only with their ethnic group but people from other cultures. It is required that FL teachers introduce the notion of diversity. Ethnic diversity can influence not only the educational process, the way a language is understood and learnt but also the way students communicate with each other. In an ethnically homogeneous group students tend to cooperate better and build trust quicker. This is an important peculiarity that should not be overlooked. 


\section{Review of Literature}

Several studies have been carried out on problems of teaching culturally diverse students in English learning environment.

Geneva Gay (2013) examines the attitudes and beliefs about ethnic and cultural diversity; resisting resistance or countering opposition to cultural diversity; centering culture and difference in the teaching process; and establishing pedagogical connections between culturally responsiveness and other dimensions or areas of teaching. The researcher emphasizes the need to use different pedagogical techniques to improve students' performance from various ethnic groups - one that teaches to and through their personal and cultural strengths, their intellectual capabilities, and their prior accomplishments (Gay, 2013). Garcia (1991) presents the set of specific guides for linguistically and culturally diverse students such as challenging students intellectually, relating academic content to the students' own environment and experience, applying a variety of skills acquired in learning environment, getting students involved in group projects, interactive activities (Garcia, 1991: 6-7).

The approaches to the classification of foreign language learners' errors were investigated by Lee (1990), Larsen-Freeman and Long (1991), Choybonova (2004). Language interferences (orthographic interference, phonological interference, lexical interference) were outlined by Choroleeva (2009). Typical mistakes in studying foreign language in non-linguistic high school were studied by Vodopyanova and Gulyan (2015).

Idealizing Standard English devalues non-standard varieties, some language teachers diminishing their own local varieties of English. For example, the omission of past tense ending can be observed in Singlish: "What happen yesterday?"; in Indian English many mass nouns become pluralized, for example, "furnitures", "litters", "woods".

Thus, teaching only local variety of English may lead to a problem of mutual understanding outside the region, so teachers are to take into account the fact that their learners may potentially encounter international English in their future work; their intercultural and strategic competence in interacting with people with other English varieties should be developed. According to Jenkins (2006: 174) students need "to adjust their speech which is intelligible to interlocutors from a wide range [first language] backgrounds, most of whom are not inner circle native speakers". Facing communication breakdown strategic competence helps learners negotiate the meaning, for instance, asking to slow down or to repeat, not feeling awkward at the same time. Intercultural competence assists interlocutors to overcome sociolinguistic differences, fostering greater tolerance for the uniqueness of one's own traditions and customs.

It is generally believed that the Russian language belongs to the Expanding circle with English being a secondary thing in people's lives. However, the role of both languages should not be underestimated, as in accordance with the theory of Kirkpatric (2007) non-native speakers may contribute a lot to the development of a local variant of English. Nonetheless, "as learners, non-native speakers in the Expanding Circle are not given the right to their own variety-development, but are seen as norm-dependent" (Mollin, 2006). D. Graddol (1997) claims that "English as a global lingua franca requires intelligibility and the setting and maintaining of standards".

The term "Runglish" appeared in 2000 as one of the languages used aboard the international Space Station, which is a mixture of English and Russian (Feuer, 2005). Russian English is acknowledged within a paradigm of the World Englishes rather than as a separate variant, still recognizing the significance of identity of Russian English. We would consider it as a certain dialect. Nowadays incorporating English words into Russian and vice versa is a common thing, especially for those

XLinguae, Volume 10 Issue 4, October 2017, ISSN 1337-8384, eISSN 2453-711X 
who have moved to the UK or the USA and work and communicate mostly in Russian surroundings. In this case English words that are frequently used in everyday situation tend to replace Russian ones.

\section{Methodology}

The following methods have been used in our research: observation, the method of identifying language errors in speech in accordance to the following criteria: types of mistakes and origin of mistakes. Systematization and generalization of facts and concepts were also used in the process of investigation.

\section{Results and discussion}

4.1 Where is the border between Standard English and Non Standard?

The Cambridge Dictionary states that 'a standard language is a variety of language that is used by governments, in the media, in schools and for international communication', while the term of Non Standard English is not defined as it is still being discussed. Nordquist (2017) suggests there are two mostly widespread views: Non Standard English is considered to be any dialect of English which differs from Standard English. On the other hand, the term is used disapprovingly by some nonlinguists to describe 'poor or incorrect English'. The question arises whether it should be taught then?

Advocates of Standard English still acknowledge that changes in the language are inevitable. Different forms are considered standard in different sources. In terms of educational institutions speaking and writing in Standard English is a must.

However, this idea seems to be a bit radical as the English language used worldwide is not purely standard. Besides, there are some situations when a person has to communicate with those who studied a local variety of English (Non Standard English - altered or omitted forms, different spelling or pronunciation). Therefore, it is logical to use Standard English as a basis for teaching and at the same time to prepare students for possible alternatives when it comes to speaking English.

Another problem which arises when teaching English as a foreign language in non-English speaking countries is a compelling challenge of linguistic diversity. It results from ethnic diversity that influences the linguistic side of teaching English. Linguistic diversity presupposes different ways of using English. It can appear in all the layers of the language: grammar, lexis, phonetics. These differences are the outcome of various ways of learning English affected by different factors: teaching, background, circumstances, learning resources syllabus and educational programs. However, the most influence comes from the ethnic diversity of the students themselves, meaning that the mother tongue always has an impact on the way one acquires a foreign language, particularly English.

We conducted research into exploring the errors in a culturally diverse classroom at the Financial University of the Russian Federation. The participants of the study were an ethnically diverse group of students from Russia and Vietnam with the specific focus on culturally induced behavior of Russians.

Ethnic diversity in the group was seen at the early stage of the experiment. The observation method revealed the following features:

- both Russian and Vietnamese students are not used to studying together a culturally diverse environment

- they have always been taught English in an ethnically homogeneous group

- unlike Russian students Vietnamese learners were always taught English in their country with the use of mother tongue for explanation. They find it challenging to adapt to studying all the courses in English. 
- new circumstances encourage both Russian and Vietnamese students to cooperate and to work efficiently.

One of the difficulties they have is pronunciation peculiarities. EFL teaching in Russia mainly focuses on Standard English with the emphasis on grammar, phonetics and complex structures while other countries have switched to a communicative method targeted at students' reasoning and critical thinking. Therefore, Russian and Vietnamese learners fail to understand each other due to their different educational backgrounds and the ways they express themselves. As to Vietnamese students' pronunciation of English words, it is strongly influenced by their language phonetic peculiarities, which complicates communication process. This presents a challenge for both cultures in an ethnically diverse classroom. Under the circumstances FL teachers play an important role in introducing everyone to the notion of ethnic diversity and making students cooperate despite either significant linguistic diversity or linguistic interference caused by imposing one language system upon another, triggering a great number of phonetic, grammar, lexical and syntactical errors.

\subsection{Phonetic errors}

Errors made by Russian native speakers can be divided into the following categories: phonetic, grammar, lexical and syntactical errors. At the phonetic level interference is considered to be the most prominent one owing to the fact that pronouncing skills are the least monitored in speech production together with speech perception. Plus, if we speak about an ethnically homogeneous group - for example, a group that includes only Russian students - they often pay less attention to their pronunciation due to the fact that they will still understand each other, as their pronunciation mistakes are similar and tend to have the same 'background' (Table 1).

Table 1: Different types of phonetic mistakes made by Russian students

\begin{tabular}{|c|c|c|}
\hline Types of mistakes & Origin of mistakes & Examples \\
\hline $\begin{array}{l}\text { Mispronunciation of } \\
\text { the interdental and } \\
\text { interlabial sound }\end{array}$ & $\begin{array}{l}\text { No similar sound in } \\
\text { Russian }\end{array}$ & $\begin{array}{ll}\text { 1. } & {[\partial=>\mathrm{d} / \mathrm{z}] \text { e.g. the }[ð ə]=>} \\
& {[\mathrm{z \partial}]} \\
2 . & {[\theta=>\mathrm{t} / \mathrm{s}] \text { e.g. thin }[\theta \mathrm{In}]=>} \\
& {[\sin ]} \\
3 . & {[\mathrm{w}]=>[\mathrm{v} / \mathrm{u}] \text { e.g. well } \Rightarrow} \\
& {[\mathrm{vel} / \mathrm{uel}]}\end{array}$ \\
\hline $\begin{array}{l}\text { Non-differentiation of } \\
\text { the length of long and } \\
\text { short vowels }\end{array}$ & $\begin{array}{lr}\text { No similar } \\
\text { phenomenon in } \\
\text { Russian }\end{array}$ & $\begin{array}{ll}\text { 1. } & \text { sit [sit] and seat [si:t] } \\
\text { 2. } & \text { live [liv] and leave [li:v] }\end{array}$ \\
\hline $\begin{array}{l}\text { Palatalization of } \\
\text { consonants preceding } \\
\text { sounds [i] }\end{array}$ & $\begin{array}{l}\text { In Russian language } \\
\text { consonants become } \\
\text { palatalized after } \\
\text { sound [i] }\end{array}$ & $\begin{array}{ll}\text { 1. } & \text { lift }[\text { lift }]=>\text { [l'ift }] \\
\text { 2. } & \text { cinema ['sinəmə] } \\
\text { ['s'snəmə] }\end{array}$ \\
\hline $\begin{array}{l}\text { Wrong stress in } \\
\text { converted nouns }\end{array}$ & $\begin{array}{lr}\text { No } & \text { similar } \\
\text { phenomenon in } \\
\text { Russian }\end{array}$ & $\begin{array}{l}\text { 1. finance - to finance } \\
\text { ['fainæns] and [faI'næns] } \\
\text { 2. commerce - to commerce } \\
\text { ['kpms:s] and [kp'ms:s] } \\
\text { 3. export - to export } \\
\text { ['eksps:t] and [Ik'sps:t] }\end{array}$ \\
\hline
\end{tabular}

XLinguae, Volume 10 Issue 4, October 2017, ISSN 1337-8384, eISSN 2453-711X 


\begin{tabular}{|l|l|l|}
\hline $\begin{array}{l}\text { Mispronunciation of } \\
\text { multi-syllable words }\end{array}$ & $\begin{array}{l}\text { No multi-syllable } \\
\text { words }\end{array}$ & Diversification, development \\
\hline Less fricative [h] & $\begin{array}{l}\text { Interference of } \\
\text { Russian }\end{array}$ & Who [hu:] => [khu:] \\
\hline $\begin{array}{l}\text { Devocalization of } \\
\text { consonant in the final } \\
\text { position }\end{array}$ & $\begin{array}{l}\text { Interference of } \\
\text { Russian }\end{array}$ & $\begin{array}{l}\text { 1.knives [naivz] => [naifs] } \\
\text { 2.robe[rəob] => [rəop] }\end{array}$ \\
\hline
\end{tabular}

Source: http://www.oxfordlearnersdictionaries.com

\subsection{Grammar errors}

Judging by the characteristics of the Russian and English language, there are a number of similarities:

- both languages function within the framework of verb tense tables that help to produce speech

- there are nouns, verbs, adjectives, adverbs, prepositions, conjunctions, pronouns

- there are three types of sentences: interrogative, affirmative and negative.

However, there are differences that cause a number of problems when students start to learn English or try to expand and deepen their knowledge. One of the most remarkable differences is the number of tenses that are used in the English language. Students struggle with correlation of tenses, ways to use them and the choice of their usage.

Bearing in mind the convergences, Russian learners face the following grammar norm deviations as shown in Table2.

Table 2: Different types of grammar mistakes made by Russian students

\begin{tabular}{|l|l|l|}
\hline Types of mistakes & Origin of mistakes & Examples \\
\hline $\begin{array}{l}\text { Omission and misuse of } \\
\text { definite and indefinite } \\
\text { articles }\end{array}$ & $\begin{array}{l}\text { No category of } \\
\text { determination in } \\
\text { the Russian } \\
\text { language }\end{array}$ & $\begin{array}{l}\text { I set up company. - I set up a } \\
\text { company. }\end{array}$ \\
\hline $\begin{array}{l}\text { Avoidance of the use of } \\
\text { Present Perfect and its } \\
\text { substitution by Past } \\
\text { Simple }\end{array}$ & $\begin{array}{l}\text { Absence of the } \\
\text { equivalent tense }\end{array}$ & $\begin{array}{l}\text { I was in Paris. - I have been } \\
\text { to Paris. }\end{array}$ \\
\hline $\begin{array}{l}\text { Use of Future tenses in } \\
\text { conditional sentences }\end{array}$ & $\begin{array}{l}\text { The use of a future } \\
\text { form in both parts } \\
\text { of a conditional } \\
\text { sentence in Russian }\end{array}$ & $\begin{array}{l}\text { If you will deliver on time, we } \\
\text { will give you a 20 percent } \\
\text { discount. - If you deliver on } \\
\text { time, we will give you a 20 } \\
\text { percent discount. }\end{array}$ \\
\hline Use of double negation & $\begin{array}{l}\text { Double negation } \\
\text { can be easily used } \\
\text { in Russian }\end{array}$ & $\begin{array}{l}\text { Our company didn't have no } \\
\text { contracts with foreign } \\
\text { partners last month. - Our } \\
\text { company didn't have any } \\
\text { contracts with foreign } \\
\text { partners last month. }\end{array}$ \\
\hline
\end{tabular}




\begin{tabular}{|l|l|l|}
\hline $\begin{array}{l}\text { Omission of the } \\
\text { prepositions, absolute } \\
\text { misuse of them }\end{array}$ & $\begin{array}{l}\text { Different rules in } \\
\text { Russian }\end{array}$ & $\begin{array}{l}\text { They are discussing the } \\
\text { influence other cultures on } \\
\text { styles of working in a } \\
\text { multinational company. }- \\
\text { They are discussing the } \\
\text { influence of other cultures on } \\
\text { styles of working in a } \\
\text { multinational company.. }\end{array}$ \\
\hline Wrong punctuation & $\begin{array}{l}\text { Different } \\
\text { punctuation rules in } \\
\text { two languages }\end{array}$ & $\begin{array}{l}\text { Take this document, if you go } \\
\text { to see the CEO of the } \\
\text { company. }- \\
\text { Take this document if you go } \\
\text { to her to see the CEO of the } \\
\text { company. }\end{array}$ \\
\hline Misuse of auxiliary verbs & $\begin{array}{l}\text { Absence of } \\
\text { auxiliary verbs in } \\
\text { Russian }\end{array}$ & $\begin{array}{l}\text { Where the HR department? }- \\
\text { Where is the HR department? }\end{array}$ \\
\hline
\end{tabular}

Most of these mistakes are provoked by the absence of analogical markers in the Russian language alongside with the use of collocation patterns of the first language. To avoid this, the teacher focuses mainly on the way students remember this material. Unlike the previous teaching practices characterized by overlooking grammar errors, today's teachers pay much attention to their correction.

\subsection{Lexical errors}

Lexical errors occur at both levels: syntagmatic and paradigmatic coming from the asymmetry of the semantic fields in the language systems. For instance, students have to understand and memorize the difference in the meaning and usages of the words do and make, cuisine and kitchen, say and tell, expect and wait as literal translation of these words into Russian coincides with the direct meaning given in the English language.

\section{Examples:}

They often $\underline{d o}$ this mistake. - They often make this mistake. - Они часто делают эту ошибку.

I loved their new cuisine, especially the furniture. - I loved their new kitchen, especially the furniture. - Мне понравилась их кухня, особенно мебель.

You shouldn't wait that he will help you. - You shouldn't expect him to help you. - Вам не следует ожидать, что он Вам поможет.

$\underline{\text { Say }}$ me everything. - Tell me everything. - Расскажите мне всё.

Paronyms are also viewed as a «stumbling block» for English learners due to the similarity in origin and sound form, for instance, personal and personnel, rise and raise.

\section{Examples:}

Personal complained about the working conditions. - Personnel complained about the working conditions. - Персонал жаловался на условия труда.

There is no need to rise the price. - There is no need to raise the price. Нет необходимости повышать цену.

Another example of lexical errors is false cognates, words which look and sound the same but have a different meaning: артист and an actor, аккуратный and accurate, декорация and decoration, магазин and magazine. Similar pronunciation is often the origin of such mistakes. If English and Russian words sound similarly, students think that they have the same meaning. Such words are commonly misused by students.

XLinguae, Volume 10 Issue 4, October 2017, ISSN 1337-8384, eISSN 2453-711X 
Summarizing the above mentioned examples, we conclude that Russian variant of English is neither geographical nor ethnic variety of English, derived from cross-cultural and cross-linguistic interference.

\subsection{Strategies to improve EFL students' errors}

Teachers usually encounter several problems while correcting students' errors: investigating the cause of the error, creating the techniques by which they can interact with the students correcting their errors, evolving strategies to prevent student from repeating the same errors in the future.

In case of pronunciation challenges and possible mistakes, one of the ways to help students to pronounce the words better is the use of one of the strategies to improve pronunciation (Table 3).

Table 3: Strategy to improve FL students' pronunciation

\begin{tabular}{|l|l|}
\hline Strategy & Examples (Zorian-Lynn, 2015) \\
\hline tongue twister & $\begin{array}{l}\text { Bobby's building business was in the business of } \\
\text { borrowing. } \\
\text { Bobby's banks building blatantly was not. } \\
\text { Ben bounced back from bankruptcy when Bella balanced } \\
\text { the books. } \\
\text { In Brisbane and Barbados, brave Brenda bribed the } \\
\text { brokers with brendy. } \\
\text { Buster believes backing Britain's bid benefits both boards, } \\
\text { The bearded barrister's briefs are in the big, black and blue } \\
\text { bag. } \\
\text { Then big, black and blue bag of briefs had better be } \\
\text { brought. } \\
\text { The bond bombed, the bond bombed, the bond bombed" } \\
\text { the brilliant, bullish brokers bleated. } \\
\text { Busy broad-based branches are bursting with business and } \\
\text { just the break you business needs. } \\
\text { Badly burned by bogus benefactors, the Burnley brothers } \\
\text { beat a retreat and bought a bar in Botswana. } \\
\text { They boasted that a billion buckets of bullion boosted the } \\
\text { market. }\end{array}$ \\
\hline
\end{tabular}

By saying a tongue twister of this type students learn to pronounce words with similar sounds but with different surroundings.

If we speak about grammar and lexical mistakes, a good way to deal with these issues is to do certain exercises - one of them is correcting mistakes. Such an exercise helps students to pay more attention to the way they speak and write, as they start to notice the mistake that they make.

Here is an example of a grammar exercise that involves the skill of correcting mistakes.

\section{Correct the mistakes in the following sentences:}

1) Are you agree to the terms of the contract?

2) I'm afraid to the failure of negotiations.

3) I'm not very good for speaking on public.

4) I'm thinking of to stay after work because there are a lot of things to do. 
5) Do you like to go out for lunch to negotiate the terms of the contract?

6) I don't make presentations good.

7) How did you made payments for the goods?

8) Meeting today was really bored.

In case of lexical mistakes, a good type of exercise is a multiple choice exercise when students need to choose the right answer. It helps to focus their attention on the difference between the given options.

Choose the right answer:

1) I walk the newspaper shop on my way to the office every morning.
a) past
b) passed
c) pass

2) British businessmen are always complaining about the during a small talk.
a) weather
b) whether
c) wether

3) The Market Leader books sold more than any other Student's book.
a) editions
b) copies
c) publications
4) I don't like my boss. She's always gossiping and lies about other people.
a) telling
b) saying
c) speaking
5) My uncle is a top lawyer and he has
a) much
b) lots
c) a lot of money.

6) These negotiations are so boring. What time do they

a) finish

b) final

c) close

7) $\mathrm{He}$ is considered to be a very person.
a) economic
b) economical
c) economics
8) Our national
a) economics
b) economy
c) economic 


\section{Conclusion}

Thus the main objective of teachers working with culturally diverse students is creating a welcoming environment in which all students can develop their skills and be productive. It is very important to practice good communication, genuine listening and different types of reading in the culturally diverse classroom. The special methodological techniques and strategies mentioned above will be really helpful to prevent students from negative feelings of inadequacy about their pronunciation, grammatical errors, limited vocabulary, and lack of information about cultural patterns within their new community. The emphasis on the cultural background, showing respect towards cultural heritage can be beneficial for students in terms of unique experiences they gain during the learning process.

\section{Bibliograpic references}

ALEFIRENKO, N. 2015. Language as a State of Ethno-Cultural Consciousness. In: XLinguae, vol.8, n. 3, pp.2-18. ISSN 1337-8393.

BIROVA, J. - KLIMOVA, I.I. - KALUGINA, O. 2016. Some critics on language education assessment. Mathematics Education, vol. 11, n. 7, pp. 2470-2482. ISSN 2468-4945.

CHOROLEEVA, K. 2009. Language Transfer: Types of Linguistic Errors Committed by Francophones Learning English as a Second Foreign Language. In: Humanising language teaching, vol. 11, n. 5, pp.110-123. ISSN 1755-9715.

CHOYBONOVA, B.M. 2004. Language errors in learners' speech at the elementary level of intensive English course: Method of individual and group motivation: dis. ... Cand. of Pedagogy. Moscow. 261 p. Available online: http://www.dissercat.com/content/yazykovye-oshibki-v-rechi-obuchayushchikhsyana-nachalnom-etape-intensivnogo-obucheniya-angl

DESMET, K. - ORTUNO-ORTIN, I. - WACZIARG, R. 2014. Culture, Ethnicity and Diversity. Working paper. UCLA.

EROKHINA E.A. 2013. Ethnic diversity as a research concept and a socio-cultural phenomenon. In: Siberian Philosophical journal, vol. 11, n.1, pp. 47-53. ISSN 25417517.

FEUER, A. 2005. For the Thirsty Runglish Speaker: Try an IzedCiawfeh. The N.Y. Times 14 June. Available: online: http://query.nytimes.com/gst/fullpage.html?res=9E01E3DD133EF937A25755C0A96 39C8B63

GARCIA, E. E. 1991. The education of linguistically and culturally diverse students: effective instructional practices. Educational Practice Report: 1. Available online: http://files.eric.ed.gov/fulltext/ED338099.pdf

GAY G. 2013. Teaching To and Through Cultural Diversity. In: Curriculum Inquiry, vol. 45, n.1, pp. 48-70. ISSN 1467-873X.

GRADDOL, D. 1997. The Future of English? London: British Council. Chapter 5 reprinted in Burns, A. and Coffin, C. (eds) 2001, pp. 26-37.

HOWARD, J. 2010. The Value of Ethnic Diversity in the Teaching Profession: A New Zealand Case Study. In: International Journal of Education, vol. 2, n. 1, pp. 122. ISSN 1948-5476.

KALUGINA, O.A. 2016. Development of students' professional communicative competence in an economic higher school. In: XLinguae Journal, vol. 9, n. 4, pp: $37-$ 45. ISSN 1337-8393.

KIRKPATRICK, A. 2007. World Englishes. Implications for international communication and English language teaching. Cambridge: Cambridge University Press. 265p. ISBN-13 978-0-521-61687-4.

LADSON-BILLINGS, G. 1995.Toward a theory of culturally relevant pedagogy. In: American Educational Research Journal, vol. 32, n. 3, pp. 465-491. ISSN 0002-8312. 
LARSEN-FREEMAN, D. - LONG, M.H. 1991.An Introduction to Second Language Acquisition. London and New York: Longman. 398 p. Available online: http://escholarship.org/uc/item/3165s95t

LEE, C. D. 2007. Culture, literacy, and learning: Taking bloom in the midst of the whirl wind. New York: Teachers College Press. 256 p. ISBN-10: 0807747483.

LEE, N. 1991.Notions of "Error" and Appropriate Corrective Treatment. Hong Kong Papers in Linguistics and Language Teaching, vol.14. Pp.55-70. Available online: https://eric.ed.gov/?id=ED354747

LEONTYEVA, T. - DOROZHKIN, E. - SHCHETININA, A. - TABAROV, K. 2016. Using the Results of Ethnolinguisticin Studies Teaching the Russian Language as a Foreign Language (by the Material of Education Lexis in Russian and Tadjik Languages). In: XLinguae, vol. 9, n. 4, pp. 100 - 107. ISSN 1337-8393.

LOEWEN, J. W. 1995. Lies my teacher told me: Everything your American history textbook got wrong. New York: New Press.

MCCARTY, T. L. 2002. A place to be Navajo; Rough Rock and the struggle for selfdetermination in indigenous schooling. Mahwah: Erlbaum. 229 p. ISBN 0805837604.

MOLLIN, S. English as a Lingua Franca: A New Variety in the New Expanding Circle. In: Nordic Journal of English Studies, vol. 5, n. 2, pp. 41-57. ISSN 1654-6970. MUSTAFINA, D.N. 2016. From the history of language policy in the U.S. education system. Available online: kpfu.ru/portal/docs/F1855388985/Mustafina.pdf

NORDQUIST, R. 2017. Nonstandard English Definition and Examples. Glossary of Grammatical and Rhetorical Terms. Available online: https://www.thoughtco.com/what-is-nonstandard-english-1691438

OAKES, J. 2005. Keeping track: How schools structure inequality (2nd ed.). New Haven, CT: Yale University Press. 333 p. ISBN 0-300-10830-3.

OXFORD LEARNER'S DICTIONARIES. Available online: http://www.oxfordlearnersdictionaries.com

PAI, Y. 1990. Cultural foundations of education. New York: Merrill/Macmillan. ISBN-10: 0131702815.

SPRADLIN, L. K. - PARSONS, R. D. 2008. Diversity matters: Understanding diversity in schools. Belmont, CA: Thomson Wadsworth. 304 p. ISBN-10: 1111341672.

VILLEGAS, A. M., Dispositions in teacher education: A look at social justice. In: Journal of Teacher Education, vol. 58, n. 5, pp. 370-380. ISSN 00224871.

VLLARREAL, F. 2009. Language Teaching to Immigrants Study on Linguistic Integration Policies in Three European Countries and Challenges for Spain. $80 \mathrm{p}$. ISBN 978-84-8417-340-3.

VODOPYANOVA, O.S. - GULYAN, G.G. 2015. Typical mistakes in studying foreign language in non-linguistic high school. Research paper. Kuban state technological university, n.11. Available online: http://ntk.kubstu.ru/file/642

VASBIEVA, D.G. - KALUGINA, O.A. 2016. An Analysis of Students' Intercultural Competence Levels in a Non-Linguistic Higher School. In: XLinguae, vol. 9, n. 3, pp.58-69. ISSN 1337-8393.

WINDZIO, M. 2013. Integration and Inequality in Educational Institutions. Springer Science+Business Media Dordrecht, University of Bremen. 310 p. ISBN 978-94-0076118-6.

ZORIAN-LYNN, J. 2015. The Business Book of Tongue Twisters: Can You Communicate with Clarity? Herausgeber: Lulu Publishing Services. 74 p. ISBN 9781483439556 .

Words: 5045

Characters: 33384 (18,56 standard page)

XLinguae, Volume 10 Issue 4, October 2017, ISSN 1337-8384, eISSN 2453-711X 
Assoc. Prof. Yevgeniya B. Novikova, PhD

Department of Foreign Languages 2

Kharkiv National Automobile and Highway University

25 Yaroslav Mudry Str.

61002 Kharkiv

Ukraine

vasilyok@ukr.net

Assoc. Prof. Irina P. Gotovtseva, PhD

Department of Foreign Languages

Russian State Agrarian University-Moscow Timiryazev Agricultural Academy

Timiryazevskaya Str., 49

127550 Moscow

Russia

gotovtseva.irina@gmail.com

Assoc. Prof. Yevgeniya B. Novikova, PhD

Department of Foreign Languages 2

Kharkiv National Automobile and Highway University

25 Yaroslav Mudry Str.

61002 Kharkiv

Ukraine

vasilyok@ukr.net

Lecturer Alexandra A. Lukina

Lecturer Daria V. Sukhorukova

Department of Foreign Languages

Financial University under the Government of the Russian Federation

Leningradsky prospect 49

125993 Moscow

Russia

aalukina@fa.ru

dvsukhorukova@fa.ru 